\title{
A BRIEF REVIEW OF TREATMENT MODALITIES FOR NON-MELANOMA SKIN CANCER
}

\author{
HARSHIT SHAH*
}

Department of Pharmaceutical Science, School of Pharmacy, North Dakota State University, Fargo, North Dakota, USA. Email: harshit.shah@ndus.edu

Received: 05 February 2020, Revised and Accepted: 15 April 2021

\section{ABSTRACT}

NMSC (Non-melanoma skin cancer) is the most commonly occurring malignancy in Caucasians. Out of all diagnosed NMSC cases, 95\% of the cases are of basal cell carcinoma and squamous cell carcinoma. The therapeutic approaches to cure or ultimately rescue the skin area affected by NMSC include surgical methods, photodynamic therapy, radiation therapy, immunotherapy, and chemotherapy. This article aims to provide a brief overview of the preliminary mechanism of action, clinical studies, advantages, and disadvantages of currently available treatment modalities.

Keywords: Non-melanoma skin cancer, Mohs micrographic surgery, Photodynamic therapy, Chemotherapy, Immunotherapy.

(C) 2021 The Authors. Published by Innovare Academic Sciences Pvt Ltd. This is an open access article under the CC BY license (http://creativecommons.org/ licenses/by/4.0/) DOI: http://dx.doi.org/10.22159/ajpcr.2021v14i6.37049. Journal homepage: https://innovareacademics.in/journals/index.php/ajpcr

\section{INTRODUCTION}

NMSC (Non-melanoma skin cancer) is the most common malignancy across the world [1]. NMSC is also known as keratinocyte cancer [2]. As per the American Academy of Dermatology, approximately 9500 people in the United States are diagnosed with skin cancer daily. The Caucasian population is more prone to NMSCs compare to others [3]. Among different NMSC subtypes, BCC (Basal Cell Carcinoma) and SCC (Squamous Cell Carcinoma) are the most commonly diagnosed NMSC, which comprises $70 \%$ and $25 \%$ cases, respectively [4-6]. Research indicates that more than 3 million Americans are diagnosed with BCC and SCC every year, with an increase of $145 \%$ and $263 \%$ cases from 2000 to 2010 [7]. These approximations surpass the Caucasians and represent a significant health burden, including morbidity, mortality, and health-care cost. Other much less common forms of NMSC are Merkel cell carcinoma, primary cutaneous B cell lymphoma, Kaposi sarcoma, carcinosarcoma, and dermatofibrosarcoma $[8,9]$

The most common goals involved in NMSC treatment are complete removal of a tumor to avoid future remission, prevent any functional impairments occurring from tumor removal, and provide the best cosmetic outcome [10]. Accurate evaluation of the tumors' risk and remission chances is essential to determine before initiating treatment to avoid under treatment for the high-risk tumor or over treatment for the low-risk lesion [11]. Different treatment options are available for NMSCs, which include procedural approaches such as standard excision, curettage and electrodesiccation, and MMS (Mohs micrographic surgery). Other approaches include PDT (Photodynamic therapy), topical pharmacotherapy such as 5-Fluorouracil, and IQ (Imiquimod) cream. These approaches are preferred for low-risk NMSCs [12-16]. Recently approved oral therapeutic agent Vismodegib, a selective inhibitor of $\mathrm{HH}$ (Hedgehog) pathway activation, is being used for metastatic and locally advanced BCC [17].

This review will cover the available treatment for NMSC, including the primary mechanism of action, the most important clinical studies, and the advantages and disadvantages associated with the treatment approach.

\section{SURGICAL APPROACHES}

\section{MMS}

The concept of surgical removal of cancerous tissue under histologic control is identified as MMS. The technique was established by
Dr. Frederic Mohs. While working, he observed the skin cancer tissue sample from rats treated with an injection of zinc chloride solution. From the observation, he suggested a technique involving controlled in situ fixation of patients' cancer tissue by application of complex zinc chloride fixative and abstraction of a fixed layer, segmentation, marking and careful mapping, then the preparation of horizontal frozen histology section allowing analysis of entire margins of removal and identification of the left tumor in tissue. This procedure can be continued until the cancer-free area is achieved. Dr. Mohs named his new surgery technique "Chemosurgery," which states the chemical fixation of surgically excised tissue $[18,19]$. Over time, the chemosurgery method gained popularity as a treatment option, but it was associated with certain disadvantages such as more than half of a day require to fix the tissue by zinc chloride, the ability of zinc chloride paste to cause significant swelling and pain requiring hospitalization, and duration of each chemosurgery stage (almost a day) resulting in multiple-day treatment. These disadvantages made it unfavorable among patients $[20,21]$.

After a few years, a fresh tissue technique, also known as microscopically controlled excision, was developed. This technique offered several advantages over chemosurgery such as a replacement of zinc chloride with a local anesthetic, immediate processing of excised tumor, and significantly less amount of time for both patients as well as the surgeon. Multiple tissue stages can be achieved in 1 day, and the wound can be reconstructed immediately. This procedure was officially named MMS in 1985 [22]. MMS is the treatment of choice for primary and recurrent BCC located on anatomic sites requiring maximum tissue conservation for routine function. The steps in MMS include biopsy site identification, outline with marking pen, local anesthesia injection, debulking the tumor by scalpel or curette in the saucer-shaped layer, histochemical staining, and microscopic examination [23,24]. The debulking step is repeated until the tumor-free zone is achieved [25]. It has been evidenced that MMS has a cure rate of 99\% for primary BCC [26]. In terms of recurrence, the chances of recurrence are $5.6 \%$ with MMS, which is $17.6 \%$ for standard excision, $9.8 \%$ for radiotherapy, and $40 \%$ for curettage and desiccation [27].

Out of all available surgical approaches, MMS is the most preferred due to the long-term cure rate and less pain compared to other approaches [28]. The current MMS technique employs optimal margin control and conservation of healthy tissue [29-31]. MMS technique provides high cure rates due to the complete evaluation of the deep and peripheral surgical margins using frozen sections [32]. The physician 
functions as both the surgeon and pathologist for the MMS, ensuring integrated, precise removal of the tumor without significant errors introduced by involving other persons' judgment. Reconstruction is done after tumor-free surgical margins are ensured with a 100\% margin evaluation [33]. In MMS thin layers of tissue are taken only from the area of positive tumor margin, which minimizes the wound size and provides the superior outcome. In most cases, restoration of the defect after the surgery can be done on the same day. However, MMS has disadvantages such as long surgical treatment period, inability to perform the surgery on patients who cannot tolerate surgery under local anesthesia, and difficulty in clearing margins for aggressive tumors involving deep structures, such as bone or parotid gland [18]. Complication like difficulties in homeostasis is associated with the MMS [10].

\section{Standard surgical excision (SSE)}

SSE is the inpatient clinic procedure, performed under the influence of local anesthesia. It involves egg-shaped surgical removal of the tumor, and the surgical defect is closed side by side. In this technique, the variable amount of tissue is forfeited to achieve acceptable cure rates. The excised tissue is then fixed in formalin, embedded in paraffin, and stained to inspect margins microscopically [34]. SSE with predetermined margins has provided a 5-year cure rate of over $98 \%$ for BCC and $92 \%$ for SCC $[35,36]$. SSE has been linked with the histologic analysis of the excised tissue; hence, presence of tumors can be confirmed. Sometimes SSE leads to infection and hematoma formation. SSE has been linked with a high recurrence rate due to the absence of a complete surgical margin assessment [10].

\section{Curettage and electrodessication (C and D)}

The use of electrodesiccation for skin cancer started in 1911 when Clark [37] observed superficial tissue drying on the application of high voltage low current to the skin through a mono-terminal electrode [37]. Dermal curette usage started in 1870 by Piffard [38]. Several years later, Wigglesworth reported the use of curette in various dermatological conditions such as Psoriasis and Syphilitic Condylomata [39]. In 1906, Fox introduced the Fox model of a curette, which is the most famous curette model until now [38].

In this technique, the lesion is infiltrated with the local anesthesia to perform the biopsy, followed by a visible tumor is electrodessicated and then curetted to remove the central portion of the tumor. It is easy to remove the central part of the tumor using this technique, but precautions should be taken when the procedure is being used to remove the peripheral portion of the tumor to avoid recurrence. The number of C and D cycles depends on tumor location [40]. C and D technique is widely used for the treatment of benign and selected malignant cutaneous neoplasm. C and D are used for low-risk BCC and SCC but not used for high-risk BCC due to a high recurrence rate [10,41-45]. The success rate of $C$ and $D$ has been entirely dependent on the physician's experience. 5-year cure rate obtained after C and D of primary, nonfibrosing BCCs of medium and high-rank areas of the face having a size $<1 \mathrm{~cm}$ when operated by a skilled surgeon is $98.8 \%$ [46]. However, it has been observed that as the size increases to $2 \mathrm{~cm}$ or more, the cure rate was reduced to $95.5 \%$ and $84 \%$, respectively [47]. The use of $\mathrm{C}$ and $\mathrm{D}$ has been widely praised and also severely criticized. $\mathrm{C}$ and $\mathrm{D}$ are considered as a reasonable, least expensive, and fastest method among all treatment approaches for NMSC $[10,45]$. The disadvantages associated with $\mathrm{C}$ and $\mathrm{D}$ are more care required for the generated wound and a slower healing rate. It often produces a white atrophic scar, which is unacceptable by the patient and also results in the recurrence of highrisk BCC [45].

\section{CRYOTHERAPY}

Cryotherapy involves the continuous application of liquid nitrogen $\left(-196^{\circ} \mathrm{C}\right)$ to the tumor and a small surrounding area [48] till the temperature of the skin reaches $-60^{\circ} \mathrm{C}$ measured by inserted temperature probe [10]. During the freezing cycle with subzero temperature, the tumor site undergoes sloughing of the damaged tissue, followed by healing. The subzero temperature causes cellular changes resulting in cell death. It is recommended that at least two freeze-thaw cycles of 40-60 s are required for the destruction of malignant lesions, including BCC [49]. Cryotherapy can be used for low-risk BCC but not for high-risk BCC due to the high recurrence rate. Sometimes, it is combined with curettage, known as curettage and cryotherapy [10]. A systemic review of the recurrence rate for 27 years indicated that cryotherapy has a recurrence rate of $4-17 \%$ [50]. It is maybe because there is no histologic confirmation of tumor-free area after cryotherapy [49].

The advantage associated with the therapy is the low-cost procedure for low-risk NMSC when the patient cannot undergo radiotherapy or surgery [10]. The success rate of the treatment is operator-dependent. Cryotherapy requires an extended healing time compared to the sutured wound. The overall relapse rates are high for primary and recurrent BCC $[26,27]$. In cryotherapy, the patient experiences pain and swelling after the treated area is thawed. The pervasive adverse effects are pigment loss, atrophy, and hypertrophic scarring. Motor and sensory neuropathies are uncommon adverse effects.

\section{PDT}

The non-invasive photodynamic treatment involves the use of light, oxygen, and photosensitizer [6,51]. On exposure to light from the monochromatic or polychromatic light source, the photosensitizer undergoes a photochemical reaction, which generates singlet oxygen species $\left({ }^{1} \mathrm{O}_{2}\right)$ and other ROS (Reactive oxygen species) having the capacity to kill the cancer cells [52-55]. The anti-tumoral effect arises from three principle mechanisms; direct cytotoxicity on cancer cells, indirect impact as a consequence of damaged tumor vasculature, and activation of the immune response [51]. Principle compounds used in PDT are ALA (5-Aminolevulinic acid) and its MALs (Methylated derivatives).

ALA is applied topically or administered systemically. In the cytosol, ALA is taken up by enzymatic equipment of heme synthesis and converted to PPIX (protoporphyrin IX), a substance essential for photosensitizing activity. On exposure to light, PPIX absorbs the provided photo energy and initiates molecular electronic transition leading to photodynamic reactions. These reactions produce ROS and bring out cancer cell death [56-62].

As per the research done by various groups, it has been proven that PDT is effective in treating superficial BCC, SCC, and AK (actinic keratosis) but it is not currently recommended for invasive SCC and aggressive BCC $[14,15]$. A retrospective study published by Christensen et al. [63], in which 44 BCC patients, with 60 histopathologically confirmed BCC lesions, were treated for 6 years with ALA PDT. This treatment resulted in the complete remission of the lesion in $81 \%$ of the patient population [63]. Wang et al. performed a Phase III study comparing the effect of ALA PDT with cryosurgery on 88 patients with basal cell epitheliomas. On analysis, it was observed that ALA-PDT provides a similar result to that of cryosurgery with the advantage of a better cosmetic outcome [64]. Apart from this, a study performed evaluating the effect of PDT on nevoid BCC syndrome (Gorlin-Goltz syndrome) concluded that blue light-activated topical $20 \%$ ALA at a fluence rate of $10 \mathrm{~mW} / \mathrm{cm}^{2}$ for $1000 \mathrm{~s}$ is efficient in managing Gorlin-Goltz syndrome $[65,66]$.

Apart from ALA, MAL is also a very safe and efficient PDT molecule being used in the management of BCC and SCC. Soler et al. [67] published a study in which the therapeutic effectiveness of MAL was analyzed on 350 superficial BCC lesions. On application, complete remission in more than $85 \%$ of the lesion was observed, and $89 \%$ of them were able to maintain remitted status for more than 3 years with good or excellent cosmetic outcomes [67]. MAL-PDT is also efficient in treating lesions present at challenging to treat positions such as periorificial, nasal region, auricular pavilion region, or the region having potential chances for developing surgical complications or in patients who are on anticoagulant therapy or at cardiovascular disease risk [68]. Similar to ALA, MAL is also efficient in treating patients suffering from 
Gorlin-Goltz syndrome [69]. Moreover, PDT can also be combined with other treatment modalities such as electrosurgery, lasers, IQ, 5-FU (5-fluorouracil), IM (ingenol mebutate), and topical retinoids for NMSC treatment [51]. PDT is also useful in reducing the incidence of AK and SCC in patients who are on long-term immunosuppressive therapy due to organ transplants $[14,15]$. PDT has tolerable side effects such as pain, burning sensation, erythema, edema, and low cost make PDT more favorable [10].

\section{RADIATION THERAPY}

Radiation therapy is another approach to treat NMSCs since the 1900s, but the use was declined after the development of MMS [70]. However, with the advancement in technology resurgence in radiation therapy has been observed, identified as SRT (superficial radiation therapy) [71]. It is being used as primary therapy and/or adjuvant therapy for NMSC [10]. There are three methods currently used for radiation therapy, which are orthovoltage or superficial X-ray, megavoltage, and brachytherapy. Orthovoltage range from 75 to $125 \mathrm{kV}$ and is used when tumor thickness is $<5 \mathrm{~mm}$. More commonly used megavoltage therapy uses an electron beam of 6-20 MeV strength and is capable of penetrating tissue up to $6 \mathrm{~cm}$. Brachytherapy uses a radioactive substance, which is applied on the surface or is placed interstitially [72]. In brachytherapy, energy is imparted on rapidly dividing tumor tissue to inhibit mitosis [71]. In a retrospective analysis performed by Schulte et al. [73], in which SRT was used to treat a total of 1267 NMSCs with an overall dose of 6100 unit gray (cGy) for BCCs and 6360 cGy for SCCs in a dose fractionation manner for either 3 times/week or 6 days/week. Patients were examined for a mean duration of 6.5 years. A recurrence rate of $5.1 \%$ was found for all NMSCs combined [73].

The advantage of external radiotherapy is that the maximum dose of radiation can be targeted to the skin surface, and it is less likely to penetrate through eye shields, which makes it favorable to use around the eyes [74]. Radiotherapy is preferred in cases where the patient disagrees with the surgical procedure, the surgery likely to compromise the vital function, or the surgery is contraindicated due to medical reasons. On the contrary, radiotherapy is an expensive treatment requiring 15-30 clinic visits to reduce poor cosmetic results by fractionizing the dose. Radiation therapy is contraindicated in patients suffering from xeroderma pigmentosum because they risk impairing DNA damage repair by ionizing radiation [75-77].

Radiotherapy is associated with complications such as desquamation, alopecia, atrophy, pigmentary changes, telangiectasia, fibrosis, ectropion, parotitis, buccal mucositis, tooth loss, gingivitis, and a loss of salivary glands are associated with the use of radiation therapy. Moreover, severe complications such as soft tissue or bone necrosis, cataracts, conjunctival scarring, or eyelid deformity are linked to radiotherapy [78].

\section{CHEMOTHERAPY AND IMMUNOTHERAPY}

Systemic chemotherapy has a key role in the management of advanced, metastasized NMSC, inoperable lesions due to size and location, patient age, and general medical condition likely to cause functional impairment if treated by excision [79]. Different topical formulations containing 5-FU, IQ, IM, retinoids are being used for the management of BCC. Selected immunomodulators belonging to the class of EGFR (epidermal growth factor receptor) inhibitors such as Cetuximab and Panitumumab can also be used since EGFR is also involved in the pathogenesis of SCC $[80,81]$. Systemic drugs like Vismodegib are another drug used in the treatment since the involvement of the $\mathrm{HH}$ in the NMSC progression. Newer therapies are developed that target PD-1 (Programmed death-1) immune checkpoint receptors and ligands. Anti-PD-1 antibodies are found to be useful to patients who have failed to respond to smoothened inhibitors such as Vismodegib and other chemotherapeutic agents such as Paclitaxel and Cisplatin [82].

5-FU is the standard treatment modality for AKs from 1960 [83-85]. It is available in different concentrations ranges from $0.5 \%$ to $5 \%$ for the disease management. It is an antimetabolite, which binds to thymidylate synthase and inhibits the conversion of deoxyuridine to thymidine nucleotides. The reduction in nucleotide synthesis leads to a decrease in DNA, and RNA synthesis leads to decreased cell proliferation and apoptosis [85-87].

5-FU is used in a condition where multiple lesions are involved, lesions present at the difficult-to-treat site, in a condition where surgical and other conventional methods are not approachable [88-90]. There are multiple clinical studies done to analyze the efficacy of 5-FU against NMSC. The result of the clinical study, where 31 patients having superficial BCCs were enrolled and treated with 5\% 5-FU twice a day for up to 8-12 weeks, showed complete histological clearance of tumor in $90 \%$ of the cases [88]. The efficacy of 5-FU has also been tested in nodular BCCs, which was found to be less [91,92]. The use of 5-FU in SCC treatment is off the label with variable efficacy. In one open-label study, 26 histologically confirmed SCC lesions were treated with 5\% 5 -FU twice a day for 9 weeks resulted in complete clearance in $92 \%$ of the patients [93].

The use of 5-FU in the treatment of NMSC is extensive, but it is associated with concentration-related adverse events such as erythema, blistering, necrosis, erosion associated with pruritus, and burning associated with skin reactions $[85,86,94]$. Treatment with 5 -FU is contraindicated in patients with a deficiency of dihydropyridine dehydrogenase responsible for the degradation of 5-FU and pregnant women [95].

IQ is an imidazoquinoline amine approved by the FDA (Food and Drug Administration) in 1997 for the management of external genital and perianal warts. IQ is an immune response modifier, which interacts with Toll-like receptor seven located on the surface of antigen-presenting cells and modulates both innate and acquired immunity [96-98]. IQ has been reported to have apoptotic and anti-angiogenic properties [99]. It is available in topical formulation ranging from $2.5 \%$ to $5 \%$ concentration.

In a meta-analysis performed by Hadley et al. [100], IQ 5\% cream was applied twice a week for 16 weeks in patients suffering from AKs in comparison with placebo. After the treatment for 16 weeks, complete clearance was observed in $50 \%$ of the population [100]. In a randomized control trial, 128 patients were divided into four different groups based on treatment frequency, twice daily, once daily, 5 days/ week, and 3 days/week application. After 12 weeks of treatment, IQ treatment showed 100, 87, 81, and 52\% histological tumor clearance. Out of all, 5 times a week, treatment provided the best results in terms of efficacy and the least side effects [101]. In a recent randomized clinical trial, where clinical efficacy between IQ, 5-FU, and PDT was compared in 601 patients and provided treatment of IQ (once daily for 5 days for 6 weeks), 5\% 5-FU cream (twice daily for 4 weeks), and two rounds of PDT (1-week gap in between two successive rounds). After 12 months, the tumor-free percentage was $83.4 \%, 80.1 \%$, and $72.8 \%$, respectively [102].

IQ has been reported to cause moderate to severe local skin reactions such as pruritus, burning, erythema, erosions, exudation, hypopigmentation, and crusting. Conjunctivitis and keratitis are likely to occur when IQ comes in direct contact with the mucosal surface during periocular lesion treatment [102]. The use of topical steroids is contraindicated with IQ as it may cause a reduction in clinical efficacy. The patient should avoid exposure to sunlight after IQ application as it may cause sunburns [96].

IM is a macrocyclic diterpene ester obtained from a plant extract of Euphorbia peplus. IM causes cellular death in the treated area within a few hours of topical application. IM causes direct cell necrosis by mitochondrial swelling and chemoablation of the plasma membrane. Along with this, it also produces an inflammatory response through protein kinase $\mathrm{C}$ activation, which induces the elimination of residual cells [103]. IM is being used for BCC treatment, but its use is off the label 
with excellent results [104,105]. The application of IM is associated with erythema, skin flaking. In some cases, it has been reported to cause blistering, swelling, erosion, ulceration. The skin responses are intense after the application, but it becomes mild and gradually disappears after 2 or 4 weeks $[106,107]$.

Retinoids are Vitamin A derivatives, which are capable of influencing the growth and differentiation of epithelial tissue by interacting with specific cellular and nuclear receptors [108], and as a result, retinoids can control cell proliferation and differentiation, which may promote apoptosis [109]. About $0.1 \%$ Tazarotene gel was evaluated for BCC in a clinical study involving 20 patients with superficial and nodular tumors, and it produced a complete response in 53\% (11 of 13 superficial and 5 of 17 nodular lesions) of the cases after applying once a day for 8 months [110]. Retinoids may cause mild to moderate erythema, peeling dryness, burning, and pruritus.

\section{SYSTEMIC CHEMOTHERAPY}

Systemic targeted chemotherapy is an essential therapeutic approach when NMSC is in the advanced or metastasized stage. Antifungal agents have been explored as NMSC treatment because of their efficacy in inhibiting the $\mathrm{HH}$ pathway. Itraconazole and posaconazole have shown their effectiveness against NMSC, but their adverse effects made severe questions regarding their usage in clinics $[81,111]$. Vismodegib is another agent having the capacity to inhibit the sonic HH pathway and was approved in 2012 but become less favorable due to its serious adverse events [112].

Vismodegib is a synthetically derived oral inhibitor of the HH signaling pathway. This pathway is only active during embryogenesis and has a crucial role in cell growth and differentiation. In BCC, the upregulation of this pathway is due to the mutation of the PTCH (Patched 1) tumor suppressor gene, which inhibits the signaling activity of a seventransmembrane protein, that is, SMO (smoothened homolog). Inhibition of SMO signaling resulting in activation of glioma-associated oncogene family of zinc-finger transcription factors resulting in aberrant pathway activation and uncontrolled cell proliferation of keratinocyte [17]. Vismodegib binds and inactivates SMO resulting in suppression of downstream production and proliferation factors resulting in tumor suppression [17]. A multicenter, international, two-cohort, nonrandomized study evaluating safety and efficacy of vismodegib $(150 \mathrm{mg}$ daily for around 7.6 months) in 104 enrolled patients suffering from metastatic and locally advanced inoperable BCC was done. The result of the study concluded a $30 \%$ response (with no complete response) (according to RECIST (Response Evaluation Criteria in Solid Tumors) guideline) in 33 patients having metastatic BCC while in 63 patients suffering from locally advanced BCC, the response rate was $43 \%$. In this clinical trial, less than half of the patients experienced adverse events such as muscle spasms, alopecia, dysgeusia, weight loss, and fatigue [113].

Cetuximab is a chimeric Immunoglobulin G1 antibody, which is approved by the FDA for the treatment of locally advanced or metastatic SCC of the head and neck, having the capacity to inhibit EGF receptor. EGFR overexpression is associated with the activation of intracellular tyrosine kinase, which further activates multiple downstream pathways leading to cell survival, angiogenesis, and cell proliferation [114]. Cetuximab can also be administered as an intravenous infusion in combination with cisplatin or 5-FU [114].

There have been few clinical studies assessing the response of cetuximab in unresectable and inoperable SCC. In an open-label, uncontrolled, multicenter Phase II clinical study evaluating the effect of cetuximab as first-line treatment for 6 weeks in 36 patients with unresectable SCC showed disease control in $69 \%$ of the patient according to the RECIST criteria [115]. In a comparative treatment study where five patients were treated with cetuximab with radiotherapy, nine patients with carboplatin, and six patients with cetuximab alone for 2 months resulting in $80 \%, 37.5 \%$, and $33 \%$ response rate, respectively [116]. Treatment with cetuximab is associated with relatively low side effects [117].

\section{CONCLUSION}

NMSC is the most common skin cancer in the United States. As per the American Academy of Dermatology, more than 3 million people are affected by NMSC every year in the United States with an annual estimate of the 4.8 billion dollars financial burden for treatment. There are multiple therapeutic approaches available for NMSC treatment. Out of all treatment modalities, MMS is considered the most preferred one to the patients as it provides a complete cure or a very long diseasefree survival period. Apart from MMS, C and D, cryotherapy, and SSE are also used as treatment modalities, but associated unwanted effects and disease relapse rate makes them less favorable. PDT is also one of the potent approaches for the NMSC. Several studies have proved the effectiveness of PDT against SCC and AK. Research also indicates that PDT, in combination with chemotherapeutic agents like 5-FU provides more cancer cell death compared to single treatment alone. Systemic chemotherapy or immunotherapy is considered favorable approaches in conditions such as the inability of surgical approaches to treat patients, patients having advanced disease states, and highrisk BCC or SCC. Patients having multiple NMSC tumors with indistinct boundaries are treated by topical chemotherapy containing IQ and 5-FU. Vismodegib, a HH pathway inhibitor is also useful in NMSC treatment, but it is associated with a severe adverse event. A recently newer therapeutic approach like anti-PD-1 antibodies is efficacious in cases where therapies such as vismodegib, paclitaxel, or cisplatin have failed to provide relief in advanced and high-risk NMSC.

\section{AUTHOR CONTRIBUTION}

HS is responsible for writing and editing the manuscript.

\section{CONFLICT OF INTEREST STATEMENT}

The authors declare that there are no conflicts of interests.

\section{FUNDING SOURCE}

The author received no specific funding for this work.

\section{REFERENCES}

1. Linares MA, Zakaria A, Nizran P. Skin cancer. Prim Care 2015;42:645-59.

2. Albert A, Knoll MA, Conti JA, Zbar RI. Non-melanoma skin cancers in the older patient. Curr Oncol Rep 2019;21:79.

3. Zink A. Trends in the treatment and prevention of keratinocyte carcinoma (non-melanoma skin cancer). Curr Opin Pharmacol 2019;46:19-23.

4. Lomas A, Leonardi-Bee J, Bath-Hextall F. A systematic review of worldwide incidence of nonmelanoma skin cancer. Br J Dermatol 2012;166:1069-80

5. Leiter U, Eigentler T, Garbe C. Epidemiology of skin cancer. Adv Exp Med Biol 2014;810:120-40.

6. Fahradyan A, Howell AC, Wolfswinkel EM, Tsuha M, Sheth P, Wong AK. Updates on the management of non-melanoma skin cancer (NMSC). Healthcare (Basel, Switzerland) 2017;5:82.

7. Rogers HW, Weinstock MA, Feldman SR, Coldiron BM. Incidence estimate of nonmelanoma skin cancer (keratinocyte carcinomas) in the U.S. population, 2012. JAMA Dermatol 2015;151:1081-6.

8. Wollina U, Koch A, Schonlebe J, Tchernev G. Carcinosarcoma of skin a rae non-melanoma skin cancer (case review). Georgian Med News 2017;263:7-10.

9. Losquadro WD. Anatomy of the skin and the pathogenesis of nonmelanoma skin cancer. Facial Plast Surg Clin North Am 2017;25:283-9.

10. Kauvar AN, Cronin TJ, Roenigk R, Hruza G, Bennett R. Consensus for nonmelanoma skin cancer treatment: Basal cell carcinoma, including a cost analysis of treatment methods. Dermatol Surg 2015;41:550-71.

11. Jennings L, Schmults CD. Management of high-risk cutaneous 
squamous cell carcinoma. J Clin Aesthet Dermatol 2010;3:39-48.

12. Lv R, Sun Q. A network meta-analysis of non-melanoma skin cancer (NMSC) treatments: Efficacy and safety assessment. J Cell Biochem 2017;118:3686-95

13. Hamdan IM, Donnelly RF. Microneedle-assisted photodynamic therapy: Delivery of a NIR photosensitiser for the treatment of skin cancers. Photodiagn Photodyn Ther 2017;17:A63.

14. Griffin LL, Lear JT. Photodynamic therapy and non-melanoma skin cancer. Cancers (Basel) 2016;8:98.

15. Cohen DK, Lee PK. Photodynamic therapy for non-melanoma skin cancers. Cancers (Basel) 2016;8:90.

16. Cheraghi N, Cognetta A, Goldberg D. Radiation therapy in dermatology: Non-melanoma skin cancer. J Drugs Dermatol 2017;16:464-9.

17. Dlugosz A, Agrawal S, Kirkpatrick P. Vismodegib. Nat Rev Drug Discov 2012;11:437-8

18. Wong E, Axibal E, Brown M. Mohs micrographic surgery. Facial Plast Surg Clin North Am 2019;27:15-34.

19. Mohs FE. Chemosurgery in cancer, gangrene and infections. AMA Arch Derm 1957;76:155-6.

20. Stegman SJ, Tromovitch TA. Fresh tissue chemosurgery for tumors of the nose. Eye Ear Nose Throat Mon 1976;55:26-30.

21. Mohs FE. Chemosurgery for skin cancer: Fixed tissue and fresh tissue techniques. Arch Dermatol 1976;112:211-5.

22. Brodland DG, Amonette R, Hanke CW, Robins P. The history and evolution of Mohs micrographic surgery. Dermatol Surg 2000;26:303-7.

23. Nemeth SA, Lawrence N. Site identification challenges in dermatologic surgery: A physician survey. J Am Acad Dermatol 2012;67:262-8.

24. Kouba DJ, LoPiccolo MC, Alam M, Bordeaux JS, Cohen B, Hanke CW, et al. Guidelines for the use of local anesthesia in officebased dermatologic surgery. J Am Acad Dermatol 2016;74:1201-19.

25. Greenway T, Greenway T. Mohs micrographic surgery for skin cancer. Aust Dermatol 1991;32:159-64.

26. Rowe DE, Carroll RJ, Day CL. Long-term recurrence rates in previously untreated (primary) basal cell carcinoma: Implications for patient follow-up. J Dermatol Surg Oncol 1989;15:315-28.

27. Rowe DE, Carroll RJ, Day CL. Mohs surgery is the treatment of choice for recurrent (previously treated) basal cell carcinoma. J Dermatol Surg Oncol 1989;15:424-31.

28. Guy GP, Machlin SR, Ekwueme DU, Yabroff KR. Prevalence and costs of skin cancer treatment in the U.S., 2002-2006 and 2007-2011. Am J Prev Med 2015;48:183-7.

29. Lawrence CM. Mohs' micrographic surgery for basal cell carcinoma. Clin Exp Dermatol 1999;24:130-3.

30. Bernstein PE. Mohs '98: Single-procedure mohs surgery with immediate reconstruction. Otolaryngol Neck Surg 1999;120:184-9.

31. Shriner DL, McCoy DK, Goldberg DJ, Wagner RF. Mohs micrographic surgery. J Am Acad Dermatol 1998;39:79-97.

32. Abide JM, Nahai F, Bennett RG. The meaning of surgical margins. Plast Reconstr Surg 1984;73:492-7.

33. Tolkachjov SN, Brodland DG, Coldiron BM, Fazio MJ, Hruza GJ, Roenigk RK, et al. Understanding mohs micrographic surgery: A review and practical guide for the nondermatologist. Mayo Clin Proc 2017;92:1261-71.

34. Marzuka AG, Book SE. Basal cell carcinoma: Pathogenesis, epidemiology, clinical features, diagnosis, histopathology, and management. Yale J Biol Med 2015;88:167-79.

35. Rowe DE, Carroll RJ, Day CL. Prognostic factors for local recurrence, metastasis, and survival rates in squamous cell carcinoma of the skin, ear, and lip. Implications for treatment modality selection. J Am Acad Dermatol 1992;26:976-90.

36. Telfer NR, Colver GB, Morton CA. Guidelines for the management of basal cell carcinoma. Br J Dermatol 2008;159:35-48.

37. Clark WL. Oscillatory desiccation in the treatment of accessible malignant growths and minor surgical conditions. J Adv Ther 1910;29:169-83.

38. Goldman GT. The current status of curettage and electrodesiccation. Dermatol Clin 2002;20:569-78

39. Wigglesworth E. The curette in dermal therapeutics. Bost Med Surg J 1876;94:143-6.

40. Williamson GS, Jackson R. Treatment of squamous cell carcinoma of the skin by electrodesiccation and curettage. Can Med Assoc J 1964;90:408-13.

41. McDaniel WE. Therapy for basal cell epitheliomas by curettage only. Further study. Arch Dermatol 1983;119:901-3.

42. Reymann F. 15 years' experience with treatment of basal cell carcinomas of the skin with curettage. Acta Derm Venereol Suppl (Stockh) 1985;120:56-9.

43. Kauvar AN, Arpey CJ, Hruza G, Olbricht SM, Bennett R, Mahmoud BH. Consensus for nonmelanoma skin cancer treatment, Part II: Squamous cell carcinoma, including a cost analysis of treatment methods. Dermatol Surg 2015;41:1214-40.

44. Blixt E, Nelsen D, Stratman E. Recurrence rates of aggressive histologic types of basal cell carcinoma after treatment with electrodesiccation and curettage alone. Dermatol Surg 2013;39:719-25.

45. Barlow JO, Zalla MJ, Kyle A, DiCaudo DJ, Lim KK, Yiannias JA. Treatment of basal cell carcinoma with curettage alone. J Am Acad Dermatol 2006;54:1039-45.

46. Rodriguez-Vigil T, Vazquez-Lapez F, Perez-Oliva N. Recurrence rates of primary basal cell carcinoma in facial risk areas treated with curettage and electrodesiccation. J Am Acad Dermatol 2007;56:91-5.

47. Spiller WF, Spiller RF. Treatment of basal cell epithelioma by curettage and electrodesiccation. J Am Acad Dermatol 1984;11:808-14.

48. Kaur S, Thami GP, Kanwar AJ. Basal cell carcinoma--treatment with cryosurgery. Indian J Dermatol Venereol Leprol 2003;69:188-90.

49. Lewin JM, Carucci JA. Advances in the management of basal cell carcinoma. F1000Prime Rep 2015;8:53.

50. Thissen MR, Neumann MH, Schouten LJ. A systematic review of treatment modalities for primary basal cell carcinomas. Arch Dermatol 1999; $135: 1177-83$

51. Lucena SR, Salazar N, Gracia-Cazana T, Zamarron A, Gonzalez S, Juarranz A, et al. Combined treatments with photodynamic therapy for non-melanoma skin cancer. Int J Mol Sci 2015;16:25912-33.

52. Choudhary S, Nouri K, Elsaie ML. Photodynamic therapy in dermatology: A review. Lasers Med Sci 2009;24:971-80.

53. Mfouo-Tynga I, Abrahamse H. Cell death pathways and phthalocyanine as an efficient agent for photodynamic cancer therapy. Int J Mol Sci $2015 ; 16: 10228-41$

54. Henderson BW, Dougherty TJ. How does photodynamic therapy work? Photochem Photobiol 1992;55:145-57.

55. Christensen E, Warloe T, Kroon S, Funk J, Helsing P, Soler AM, et al. Mork, guidelines for practical use of MAL-PDT in non-melanoma skin cancer. J Eur Acad Dermatol Venereol 2010;24:505-12.

56. Suarez-Valladares MJ, Rodriguez-Prieto MA, Serra-Llusa R. Penetration of $630 \mathrm{~nm}$ laser and 5-aminolevulinic acid in tissue with intralesional photodynamic therapy. Photodiagn Photodyn Ther 2016;16:166-8.

57. Sotiriou E, Apalla Z, Vrani F, Lazaridou E, Vakirlis E, Lallas A, et al. Daylight photodynamic therapy vs. Conventional photodynamic therapy as skin cancer preventive treatment in patients with face and scalp cancerization: An intra-individual comparison study. J Eur Acad Dermatol Venereol 2017;31:1303-7.

58. Soleymani T, Abrouk M, Kelly KM. An analysis of laser therapy for the treatment of nonmelanoma skin cancer. Dermatol Surg 2017;43:615-24

59. Jerjes W, Upile T, Betz CS, El Maaytah M, Abbas S, Wright A, Hopper C. The application of photodynamic therapy in the head and neck. Dent Update 2007;34:478-86.

60. Apalla Z, Sotiriou E, Chovarda E, Lefaki I, Devliotou-Panagiotidou D, Ioannides D. Skin cancer: Preventive photodynamic therapy in patients with face and scalp cancerization. A randomized placebo-controlled study. Br J Dermatol 2010;162:171-5.

61. Anderson RR, Parrish JA. Selective photothermolysis: Precise microsurgery by selective absorption of pulsed radiation. Science 1983;220:524-7.

62. Anderson RR. Lasers for dermatology and skin biology. J Invest Dermatol 2013;133:E21-3.

63. Christensen E, Skogvoll E, Viset T, Warloe T, Sundstrom S. Photodynamic therapy with 5-aminolaevulinic acid, dimethylsulfoxide and curettage in basal cell carcinoma: A 6-year clinical and histological follow-up. J Eur Acad Dermatol Venereol 2009;23:58-66.

64. Wang I, Bendsoe N, Klinteberg CA, Enejder AM, Andersson-Engels $\mathrm{S}$, Svanberg S, et al. Photodynamic therapy vs. cryosurgery of basal cell carcinomas: Results of a phase III clinical trial. Br J Dermatol 2001;144:832-40.

65. Matei C, Tampa M, Poteca T, Panea-Paunica G, Georgescu SR, Ion RM, et al. photodynamic therapy in the treatment of basal cell carcinoma. 2013;6:50-4.

66. Itkin A, Gilchrest BA. Delta-Aminolevulinic acid and blue light photodynamic therapy for treatment of multiple basal cell carcinomas in two patients with nevoid basal cell carcinoma syndrome. Dermatol Surg 2004;30:1054-61. 
67. Soler AM, Warloe T, Berner A, Giercksky K. A follow-up study of recurrence and cosmesis in completely responding superficial and nodular basal cell carcinomas treated with methyl 5-aminolaevulinatebased photodynamic therapy alone and with prior curettage. $\mathrm{Br} \mathrm{J}$ Dermatol 2001;145:467-71.

68. Horn M, Wolf P, Wulf HC, Warloe T, Fritsch C, Rhodes LE, Kaufmann R, et al. Topical methyl aminolaevulinate photodynamic therapy in patients with basal cell carcinoma prone to complications and poor cosmetic outcome with conventional treatment. Br J Dermatol 2003;149:1242-9.

69. Pauwels C, Mazereeuw-Hautier J, Basset-Seguin N, Livideanu C, Viraben R, Paul C, et al. Topical methyl aminolevulinate photodynamic therapy for management of basal cell carcinomas in patients with basal cell nevus syndrome improves patient's satisfaction and reduces the need for surgical procedures. J Eur Acad Dermatol Venereol 2011;25:861-4.

70. David CV. Electronic brachytherapy and superficial radiation therapy: Will you be adding it to your practice? Cutis 2013;92:E16-8.

71. McGregor S, Minni J, Herold D. Superficial radiation therapy for the treatment of nonmelanoma skin cancers. J Clin Aesthet Dermatol 2015;8:12-14

72. Bath-Hextall FJ, Perkins W, Bong J, Williams HC. Interventions for basal cell carcinoma of the skin. Cochrane Database Syst Rev 2007;1:CD003412

73. Schulte KW, Lippold A, Auras C, Bramkamp G, Breitkopf C, Elsmann HJ, et al. Soft x-ray therapy for cutaneous basal cell and squamous cell carcinomas. J Am Acad Dermatol 2005;53:993-1001.

74. Skowronek J. Brachytherapy in the treatment of skin cancer: An overview. Postep Dermatol Alergol 2015;32:362-7.

75. Morrison WH, Garden AS, Ang KK. Radiation therapy for nonmelanoma skin carcinomas. Clin Plast Surg 1997;24:719-29.

76. Mendenhall WM, Amdur RJ, Hinerman RW, Werning JW, Villaret DB, Mendenhall NP. Head and neck mucosal melanoma. Am J Clin Oncol 2005;28:626-30.

77. Han A, Ratner D. What is the role of adjuvant radiotherapy in the treatment of cutaneous squamous cell carcinoma with perineural invasion? Cancer 2007; 109:1053-9.

78. Garcia-Serra A, Hinerman RW, Mendenhall WM, Amdur RJ, Morris CG, Williams LS, et al. Carcinoma of the skin with perineural invasion. Head Neck 2003;25:1027-33.

79. Micali G, Lacarrubba F, Bhatt K, Nasca MR. Medical approaches to non-melanoma skin cancer. Expert Rev Anticancer Ther 2013;13:1409-21.

80. Krähn G, Leiter U, Kaskel P, Udart M, Utikal J, Bezold G, et al. Coexpression patterns of EGFR, HER2, HER3 and HER4 in nonmelanoma skin cancer. Eur J Cancer 2001;37:251-9.

81. Amaral T, Garbe C. Non-melanoma skin cancer: New and future synthetic drug treatments. Expert Opin Pharmacother 2017;18:689-99.

82. Falchook GS, Leidner R, Stankevich E, Piening B, Bifulco C, Lowy I, et al. Responses of metastatic basal cell and cutaneous squamous cell carcinomas to anti-PD1 monoclonal antibody REGN2810. J Immunother Cancer 2016;4:70.

83. Askew DA, Mickan SM, Soyer HP, Wilkinson D. Effectiveness of 5-fluorouracil treatment for actinic keratosis--a systematic review of randomized controlled trials. Int J Dermatol 2009;48:453-63.

84. Klein E, Milgrom H, Helm F, Ambrus J, Traenkel HL, Stoll HS. Tumors of the skin: Effects of local use of cytostatic agents. Skin (Los Angeles) $1962 ; 1: 81-7$

85. Micali G, Lacarrubba F, Dinotta F, Massimino D, Nasca MR. Treating skin cancer with topical cream. Expert Opin Pharmacother 2010;11:1515-27.

86. McGillis ST, Fein H. Topical treatment strategies for non-melanoma skin cancer and precursor lesions. Semin Cutan Med Surg 2004:23:174-83

87. Weinberg JM. Topical therapy for actinic keratoses: Current and evolving therapies. Rev Recent Clin Trials 2006;1:53-60.

88. Gross K, Kircik L, Kricorian G. 5\% 5-Fluorouracil cream for the treatment of small superficial Basal cell carcinoma: Efficacy, tolerability, cosmetic outcome, and patient satisfaction. Dermatol Surg 2007;33:433-9; discussion 440.

89. Romagosa R, Saap L, Givens M, Salvarrey A, He JL, Hsia SL, et al. A pilot study to evaluate the treatment of basal cell carcinoma with 5-fluorouracil using phosphatidyl choline as a transepidermal carrier. Dermatol Surg 2000;26:338-340.

90. Klein E, Stoll HL, Milgrom H, Case RW, Traenkle HL, Graham S, et al. tumors of the skin. IV. double-blind study on effects of local administration of anti-tumor agents in basal cell carcinoma. J Invest Dermatol 1965;44:351-3.

91. Shelley WB, Wood MG. Nodular superficial pigmented basal cell epitheliomas. Arch Dermatol 1982;118:928-30.

92. Ceovic R, Smolkovic N, Pasic A, Kostovic K, Hrsan D. Multiple basal cell carcinomas of lower legs with stasis dermatitis: A therapeutic challenge. Acta Dermatovenerol Croat 2012;20:191-6.

93. Bargman HB, Hochman J. Topical treatment of Bowen's disease with 5-fluorouracil. J Cutan Med Surg 2003;7:101-5.

94. Stockfleth E, Kerl H, Zwingers T, Willers C. Low-dose 5-fluorouracil in combination with salicylic acid as a new lesion-directed option to treat topically actinic keratoses: Histological and clinical study results. Br J Dermatol 2011;165:1101-8.

95. Johnson MR, Hageboutros A, Wang K, High L, Smith JB, Diasio RB. Life-threatening toxicity in a dihydropyrimidine dehydrogenasedeficient patient after treatment with topical 5-fluorouracil. Clin Cancer Res 1999;5:2006-11.

96. Lacarrubba F, Nasca MR, Micali G. Advances in the use of topical imiquimod to treat dermatologic disorders. Ther Clin Risk Manag 2008;4:87-97.

97. Patel GK, Goodwin R, Chawla M, Laidler P, Price PE, Finlay AY, et al. Imiquimod 5\% cream monotherapy for cutaneous squamous cell carcinoma in situ (Bowen's disease): A randomized, double-blind, placebo-controlled trial. J Am Acad Dermatol 2006;54:1025-32.

98. Schon M, Schon MP. The antitumoral mode of action of imiquimod and other imidazoquinolines. Curr Med Chem 2007;14:681-7.

99. Li VW, Li WW, Talcott KE, Zhai AW. Imiquimod as an antiangiogenic agent. J Drugs Dermatol 2005;4:708-17.

100.Hadley G, Derry S, Moore RA. Imiquimod for actinic keratosis: Systematic review and meta-analysis. J Invest Dermatol 2006;126:1251-5.

101.Geisse JK, Rich P, Pandya A, Gross K, Andres K, Ginkel A, et al. Imiquimod $5 \%$ cream for the treatment of superficial basal cell carcinoma: A double-blind, randomized, vehicle-controlled study. J Am Acad Dermatol 2002;47:390-8.

102.Arits AH, Mosterd K, Essers BA, Spoorenberg E, Sommer A, De Rooij MJ, et al. Kelleners-smeets, photodynamic therapy versus topical imiquimod versus topical fluorouracil for treatment of superficial basalcell carcinoma: A single blind, non-inferiority, randomised controlled trial. Lancet Oncol 2013;14:647-54.

103. Rosen RH, Gupta AK, Tyring SK. Dual mechanism of action of ingenol mebutate gel for topical treatment of actinic keratoses: Rapid lesion necrosis followed by lesion-specific immune response. J Am Acad Dermatol 2012;66:486-93.

104.Fallen RS, Gooderham M. Ingenol mebutate: An introduction. Skin Ther Lett 2012;17:1-3.

105.Patel RV, Frankel A, Goldenberg G. An update on nonmelanoma skin cancer. J Clin Aesthet Dermatol 2011;4:20-7.

106.Lebwohl M, Swanson N, Anderson LL, Melgaard A, Xu Z, Berman B. Ingenol mebutate gel for actinic keratosis. $\mathrm{N}$ Engl $\mathrm{J}$ Med 2012;366:1010-9.

107.Amini S, Viera MH, Valins W, Berman B. Nonsurgical innovations in the treatment of nonmelanoma skin cancer. J Clin Aesthet Dermatol 2010;3:20-34

108. Mukherjee S, Date A, Patravale V, Korting HC, Roeder A, Weindl G. Retinoids in the treatment of skin aging: An overview of clinical efficacy and safety. Clin Interv Aging 2006;1:327-48.

109. Cuevas P, Angulo J, Bourdier AC, Salgüero I. Treatment of infiltrative basal cell carcinomas by inhibiting the fibroblast growth factor (FGF)signal transducer and activator of transcription (STAT)-3 signalling pathways. J Cancer Sci Ther 2012;1:S3.

110.Peris K, Fargnoli MC, Chimenti S. Preliminary observations on the use of topical tazarotene to treat basal-cell carcinoma. N Engl J Med 1999;341:1767-8.

111.Kim DJ, Kim J, Spaunhurst K, Montoya J, Khodosh R, Chandra K, et al. Open-label, exploratory phase II trial of oral itraconazole for the treatment of basal cell carcinoma. J Clin Oncol 2014;32:745-51.

112.Odom D, Mladsi D, Purser M, Kaye JA, Palaka E, Charter A, et al. A matching-adjusted indirect comparison of sonidegib and vismodegib in advanced basal cell carcinoma. J Skin Cancer 2017;2017:6121760.

113. Sekulic A, Migden MR, Oro AE, Dirix L, Lewis KD, Hainsworth JD, et al. Efficacy and safety of vismodegib in advanced basal-cell carcinoma. N Engl J Med 2012;366:2171-9.

114.Dubas LE, Ingraffea A. Nonmelanoma skin cancer. Facial Plast Surg Clin North Am 2013;21:43-53.

115. Maubec E, Petrow P, Scheer-Senyarich I, Duvillard P, Lacroix L, 
Gelly J, et al. Phase II study of cetuximab as first-line single-drug therapy in patients with unresectable squamous cell carcinoma of the skin. J Clin Oncol 2011;29:3419-26.

116.Preneau S, Rio E, Brocard A, Peuvrel L, Nguyen JM, Quereux G, et al. Efficacy of cetuximab in the treatment of squamous cell carcinoma.
J Dermatolog Treat 2014;25:424-7.

117.O'Bryan K, Sherman W, Niedt GW, Taback B, Manolidis S, Wang $\mathrm{A}$, et al. An evolving paradigm for the workup and management of high-risk cutaneous squamous cell carcinoma. J Am Acad Dermatol 2013;69:595-602.e1. 